\title{
ANALISIS KOMODITAS EMAS DENGAN KONSEP RIBA DALAM PERSPEKTIF USUL FIKIH
}

\section{ANALYSIS OF GOLD COMMODITY WITH THE CONCEPT OF USURY IN THE PERSPECTIVE OF UȘUL FIQH}

\author{
M. Dzul Fadli S. \\ Sekolah Tinggi Ilmu Islam dan Bahasa Arab (STIBA) Makassar \\ Email: wifi.fadli.dian@gmail.com \\ M. Wahyuddin Abdullah \\ Universitas Islam Negeri (UIN) Alauddin Makassar \\ Email: tosir_wahyu@yahoo.com \\ Khaerul Aqbar \\ Sekolah Tinggi Ilmu Islam dan Bahasa Arab (STIBA) Makassar \\ Email:khaerul@stiba.ac.id
}

\begin{tabular}{|c|c|c|}
\hline Keywords : & & ABSTRACT \\
\hline $\begin{array}{l}\text { gold, commodity, } \\
\text { usury }\end{array}$ & cash, & $\begin{array}{l}\text { This research aimed to reveal gold whose function as a commodity } \\
\text { has fallen out of the category așaf al-riba or not. This research was } \\
\text { prepared using the normative method or reference study by } \\
\text { examining classical ulama books. The results of this study concluded } \\
\text { that gold which functions as a commodity is not excluded from the } \\
\text { așnaf al-riba category so that the transaction must pay attention to } \\
\text { the rules of usury, including that it cannot be bought and sold without } \\
\text { cash. }\end{array}$ \\
\hline
\end{tabular}

\begin{tabular}{ll}
\hline Kata kunci : & \multicolumn{1}{c}{ ABSTRAK } \\
\cline { 2 - 3 } emas, komoditas, tunai, riba & $\begin{array}{l}\text { Penelitian ini bertujuan untuk mengungkap emas yang fungsinya } \\
\text { sebagai komoditas dihukumi telah keluar dari kategori așnaf al-riba } \\
\text { atau tidak. Penelitian ini menggunakan metode normatif atau kajian }\end{array}$ \\
& referensi dengan mengkaji kitab-kitab klasik Ulama. Adapun hasil \\
& dari penelitian ini menyimpulkan, bahwa emas yang berfungsi \\
& komoditas tidak dikeluarkan dari kategori așnāf al-riba sehinga \\
transaksinya harus memperhatikan kaedah riba, di antaranya tidak \\
boleh dijualbelikan dengan cara tidak tunai.
\end{tabular}

Diterima: 29 Desember 2020; Direvisi: 27 Mei 2021; Disetujui: 1 Juni 2021; Tersedia online: 11 Juni 2021

How to cite: M. Dzul Fadli S., M. Wahyuddin Abdullah, \& Khaerul Aqbar. "Analisis Komoditas Emas dengan Konsep Riba dalam Perspektif Usul Fikih." NUKHBATUL 'ULUM: Jurnal Bidang Kajian Islam 7, no. 1 (2021):20-37. https://doi.org/10.36701/nukhbah.v7i1.288.

\section{PENDAHULUAN}

Manusia adalah makhluk sosial yang saling membutuhkan antara satu sama lainnya guna memenuhi kebutuhannya masing-masing, sehingga merekapun melakukan 
transaksi antarsesama. Adapun transaksi-transaksi yang dilangsungkan bermula dengan cara barter yaitu tukar-menukar barang dengan barang, dalam istilah Islam dikenal dengan al-muqābaḍh, contohnya menukar buku dengan jam tangan. Seiring ditemukannya alat tukar-menukar yang memiliki nilai yang sama pada suatu barang, sehingga transaksi berubah menjadi al-bai' (jual beli) yaitu tukar-menukar antara barang dengan alat tukar seperti membeli mobil dengan uang. Kemudian berkembang menjadi al-șarf yaitu tukar-menukar antara alat tukar dengan alat tukar lainnya, seperti menukar uang dengan mata uang rupiah ke mata uang dolar. ${ }^{1}$

Ajaran Islam mengatur transaksi-transaksi dalam berekonomi yang pada dasar hukumnya adalah mubah (boleh) berdasarkan kaedah fikih al-aṣlu fì al-mu'āmalāt alibāhah yaitu hukum asal dalam transaksi-transaksi adalah boleh. Sedangkan aturanaturan yang bersinggungan dengan transaksi muqābaḍh, bai', dan șarf adalah dilarangnya praktek riba pada transaksinya, dimana salah satu harta yang ditukarkan adalah emas, yang kemudian para ulama mengkiaskannya dengan uang, sehingga dalam bertransaksi baik dengan emas ataupun uang harus memperhatikan kaedah-kaedah riba, agar transaksinya terlepas dari praktek riba yang dilarang dalam Islam.

Pada mulanya emas digunakan sebagai alat tukar untuk membeli suatu barang, dimana uang yang digunakan untuk membeli suatu barang terbuat dari emas yang dikenal dengan dinar, sehingga emas dikategorikan sebagai alat tukar dan berlaku padanya kaedah-kaedah riba seperti riba al-fạ̣l yaitu tukar-menukar antara aṣnāf alriba yang sejenis dengan nilai yang tidak semisal contohnya emas baru 2 gram ditukar dengan emas tua 3 gram, dan riba al-nasì'ah yaitu tukar-menukar așnāf al-riba yang sejenis dengan tidak tunai contohnya tukar-menukar emas dengan nilai yang sama tapi tidak tunai.

Seiring dengan perkembangan zaman uang sebagai alat tukar tidak hanya diproduksi dari emas, seperti beredarnya uang kertas dan uang logam, bahkan sudah terdapat uang yang tidak kelihatan fisiknya, yaitu uang elektronik. Selama dia menjadi alat tukar, maka berlaku pula padanya kaedah riba. Olehnya, dalam transaksi șarf yaitu tukar-menukar uang dengan mata uang yang berbeda tidak boleh secara tidak tunai karena terkena kaedah riba al-nasi'ah, begitupun antara uang kertas dengan uang elektronik tidak diperbolehkan ditukar secara tidak tunai. Karena alat tukar sudah beralih ke uang kertas dan uang elektronik, dan tidak diproduksinya lagi emas menjadi alat tukar atau uang, maka emas telah beralih fungsi dari alat tukar menjadi komoditas. Hal ini menyebabkan sebagian orang memandang emas sudah tidak termasuk dalam așnāf al-riba sehingga tidak berlaku lagi kaedah-kaedah riba padanya, seperti telah bermunculannya transaksi jual beli emas secara tidak tunai yaitu jual beli emas online, tabungan emas dan cicilan emas.

\footnotetext{
${ }^{1}$ Yusuf Syubili, Muqaddimah Fi Al-Mu'amalāti Al-Māliyah Wa Ba'dh Al-Tathbīqāt AlMu'āshirah (Makkah: Maktabah Nur, 2005), h. 2.
} 
Praktek jual beli emas secara tidak tunai telah ditemukan pada bank-bank syariah seperti pada Bank Mandiri Syariah dengan produk Cicil Emas, pada Bank BRI Syariah dengan produk Tabungan Emas, dan pada Bank BNI Syariah dengan produk Pembiayaan Emas iB Hasanah, begitupun jual beli emas tidak tunai pada lembagalembaga keuangan non Bank. Mengingat bahwa investasi emas adalah paling diminati di Indonesia, Dewan Syariah Nasional Majelis Ulama Indonesia mengeluarkan fatwa No. 77/DSN-MUI/2010 tentang jual beli emas secara tidak tunai. Isi fatwa tersebut adalah jual beli emas secara tidak tunai, baik melalui jual beli biasa atau jual beli murabahah, hukumnya boleh (mubāh, jāiz) selama tidak menjadi alat tukar yang resmi (uang). ${ }^{2}$

Fatwa Dewan Syariah Nasional Majelis Ulama Indonesia (DSN MUI) termasuk yang memandang emas bukan sebagai alat tukar melainkan memandangnya sebagai komoditas, sehingga DSN MUI membolehkan transaksi emas secara tidak tunai karena tidak termasuk lagi dalam kategori așnāf al-riba seperti emas batangan dan emas perhiasan. Adapun emas yang masih berfungsi sebagai alat tukar seperti uang koin dengan mata uang rupiah, dinar dan lain-lain, masih termasuk kategori aṣnāf al-riba sehingga kaedah riba berlaku pada emas tersebut yang tidak boleh ditransaksikan dengan al-nasì'ah. Sedangkan jual beli emas yang berfungsi sebagai alat tukar harus secara tunai.

Selain fatwa DSN MUI terdapat pendapat ulama yang lain yang tidak membedakan antara emas yang berfungsi sebagai alat tukar maupun sebagai komoditas. Oleh karena itu, artikel ini bertujuan menganalisa fungsi emas sebagai komoditas yang dapat mengeluarkannya dari kategori așnaf al-riba, atau berubah fungsinya dari sebagai alat tukar menjadi komoditas tidak memberikan pengaruh, sehingga baik emas yang berupa uang, perhiasan dan atau batangan tetap dikategorikan sebagai așnaf al-riba.

Penelitian ini sangat dibutuhkan melihat banyaknya entitas bisnis berbasis emas yang tidak mempersyaratkan taqābuḍ (serah terima tunai) dalam transaksinya dan yang menjadi landasannya adalah Fatwa DSN MUI tersebut yang menurut peneliti perlu untuk ditinjau kembali. Terdapat penelitian sebelumnya yaitu penelitian dengan judul "Jual Beli Emas Secara Tidak Tunai (Telaah Fatwa DSN-MUI No. 77/DSNMUI/V/2010)" oleh Abdul Rahman Ramli. ${ }^{3}$ Penelitian ini menyimpulkan bahwa diperbolehkannya jual beli emas secara tidak tunai berdasarkan penafsiran hadis Nabi SAW tentang jual beli emas secara kekininan dan fatwa DSN-MUI sudah sesuai dengan metode instinbāt hukum Islam dan prosedur penetapan fatwa MUI. Namun penelitian ini hanya menguraikan bagaimana prosedur penetapan fatwa MUI tersebut dan tidak mengkaji dan melakukan perbandingan dengan pendapat yang lain.

\footnotetext{
${ }^{2}$ Dewan Syariah Nasional MUI, Fatwa DSN MUI No. 77/DSN-MUI/2010 Tentang Jual Beli Emas Secara Tidak Tunai, 2010.

${ }^{3}$ Abdul Rahman Ramli, "Jual Beli Emas Secara Tidak Tunai (Telaah Fatwa DSN-MUI No. 77/DSN-MUI/V/2010)" (Universitas Muhammadiyah Surakarta, 2015).
} 
Adapula penelitian yang lain yaitu "Istidlal Fatwa Dewan Syariah Nasional Tentang Jual Beli Emas Tidak Tunai" oleh Ahmad Zakki Zamani. ${ }^{4}$ Penelitian ini membandingkan pendapat Empat Imam Mazhab dan DSN-MUI yang merujuk dari pendapat ulama kontemporer seperti Ibnu Taimiyah, Ibnu Qayyim, dan Syaikh Ali Jum'ah, sehingga menyimpulkan bahwa emas perhiasan boleh dijualbelikan tidak tunai, dan emas bukan perhiasan haram dijualbelikan tidak tunai. Menurut peneliti, penelitian tersebut belum menjawab permasalahan yang diangkat pada penelitian ini, yaitu emas yang sudah berubah fungsi dari alat tukar menjadi komoditas.

Penelitian yang lainnya, berujudul "Jual Beli Emas Secara Tidak Tunai Dalam Pandangan Ibn Taymiyyah (1263-1328 M)" oleh Imron Hamzah. ${ }^{5}$ Penelitian ini menjelaskan metode ijtihad Ibnu Taimiyyah dalam menyimpulkan bolehnya jual beli emas tidak tunai yang juga menjadi pijakan fatwa DSN-MUI, yaitu dengan metode bayāniy, ta'līliy dan istiṣhābiy, yang menurut peneliti menjadi letak permasalahan dari kesalahan penafsiran perkataan Ulama. Olehnya, dalam penelitian ini akan menjelaskan maksud dari perkataan tersebut.

Penelitian ini merupakan jenis penelitian pustaka ${ }^{6}$ yaitu berupa hasil penelitian, artikel dan buku-buku referensi yang membahas topik yang berkaitan dengan tema penelitian ${ }^{7}$, dimana peneliti mengkaji beberapa referensi dari pendapat-pendapat yang bersebrangan dan kemudian dikomparasikan untuk mendapatkan pendapat yang lebih mendekati kebenaran. Dan implikasi dari hasil penelitian ini terdapat pada hukum transaksi jual beli emas secara tidak tunai, yang mana apabila emas yang berfungsi sebagai komoditas bukan lagi dikategorikan aṣnāf al-riba maka transaksi tersebut dibolehkan, sedangkan yang berpendapat emas tersebut tetap dikategorikan așnāf alriba maka transaksi tersebut tidak diperbolehkan karena termasuk riba al-nasī’ah.

\section{PEMBAHASAN}

\section{Pengertian Riba}

Riba dalam bahasa bermakna tambahan, sedangkan dalam istilah syar'inya adalah penambahan atau pentakhiran pada tukar-menukar pada harta-harta tertentu atau apa

\footnotetext{
${ }^{4}$ Ahmad Zaki Zamani, "Iistidlal Fatwa Dewan Syariah Nasional Tetang Jual Beli Emas Tidak Tunai,” Al-Banjari: Jurnal Ilmiah Ilmu-Ilmu Keislaman 15, no. 1 (2016): 83-98.

${ }^{5}$ Imron Hamzah, "Jual Beli Emas Secara Tidak Tunai Dalam Pandangan Ibn Taymiyyah (12631328 M)" (IAIN Purwokerto, 2018).

${ }^{6}$ Azwar Iskandar and Khaerul Aqbar, "Reposisi Praktik Ekonomi Islam: Studi Kritis Praktik Ekonomi Islam Di Indonesia,” NUKHBATUL'ULUM: Jurnal Bidang Kajian Islam 5, no. 1 (2019): 3953.

${ }^{7}$ Azwar Iskandar and Khaerul Aqbar, "Kedudukan Ilmu Ekonomi Islam Di Antara Ilmu Ekonomi Dan Fikih Muamalah: Analisis Problematika Epistemologis," NUKHBATUL'ULUM: Jurnal Bidang Kajian Islam 5, no. 2 (2019): 88-105.
} 
yang ditambahkan pada pokok utang. ${ }^{8}$ Sedangkan hukumnya adalah haram berdasarkan Al-Qur'an, hadis, dan ijma' dan termasuk dari dosa-dosa besar dan tujuh hal yang membinasakan. Dan Allah tidak mengumumkan perang terhadap pelaku maksiat di dalam Al-Qur'an kecuali yang memakan harta riba, barang siapa yang menghalakannya maka ia telah kufur karena pengingkarannya terhadapa agama, adapun yang bertransaksi dengan riba sedangkan dia tidak menghalalkannya maka dia hukumi fasiq. ${ }^{9}$

Dalil-dalil dari Al-Qur'an:

Allah subhānah wa ta'ālā berfirman dalam QS. al-Baqarah/2: 275.

$$
\text { أحل الله البيع وحرم الربا }
$$

Terjemahnya:

"Allah menghalalkan jual beli dan mengharamkan riba."10

Allah subhānah wa ta' àlā berfirman dalam QS. al-Baqarah/2: 278-279

$$
\begin{aligned}
& \text { يا أيها الذين آمنوا اتقوالله وذروا ما بقي من الربا إن كنتم مؤمنين, فإن لم تفعلوا فأذنوا بحرب من } \\
& \text { الله ورسوله وإن تبتم فلكم رؤوس أموالكم لا تظلمون ولا تظلمون }
\end{aligned}
$$

Terjemahnya:

"Wahai orang-orang yang beriman, bertakwalah kepada Allah dan tinggalkanlah sisa riba (yang belum dipungut) jika kamu orang beriman. Jika kamu tidak laksanakannya, maka umumkanlah perang dari Allah dan Rasul-Nya. Tetapi jika kamu bertobat, maka kamu berhak atas pokok hartamu. Kamu tindak berbuat zalim (merugikan) dan tidak dizalimi." 11

Berkata al-Sarkhasi, "Allah menyebutkan dalam ayat ini lima hukuman atas orang yang makan harta riba: pertama, kemasukan setan, pada surah al-Baqarah: 275; kedua, kebinasaan, kehilangan keberkahan dan kenikmatan, pada surah al-Baqarah: 276; ketiga, perang dari Allah, pada surah al-Baqarah: 279; keempat, kekufuran karena menghalalkan riba, pada surah al-Baqarah: 276; kelima, kekal di neraka bagi yang menghalalkannya, pada surah al-Baqarah:275.",12

Dalil-dalil dari hadis:

Dari Abu Hurairah radiallahu 'anhu dari Nabi șallallahu 'alaihi wa sallam bersabda:

\footnotetext{
${ }^{8}$ Abd. Rahim As-Sā'atī, Al-'Illah Al-Iqtișādiyah Litahrīm Riba Al-Nasī’Ah Wa Al-Faḍl, n.d., h. 43-47.

${ }^{9}$ Syubili, Muqaddimah Fi Al-Mu'amalāti Al-Māliyah Wa Ba'dh Al-Tathbīqāt Al-Mu'āshirah.

${ }^{10}$ R I Kementerian Agama, Al-Quran Dan Terjemahnya, (Jakarta: PT. Hati Emas, 2014), h. 47.

${ }^{11}$ R I Kementerian Agama, "Al-Qur'an Dan Terjemahan," Bandung: CV Mikraj Khazanah Ilmu, 2013, h. 47.

${ }^{12}$ Syubili, Muqaddimah Fi Al-Mu'amalāti Al-Māliyah Wa Ba'dh Al-Tathbīqāt Al-Mu'āshirah.
} 


$$
\begin{aligned}
& \text { اجتنبوا السبع الموبقات قالوا: يا رسول الله وماهن؟ قال : الشرك بالله والسحر وقتل النفس التي } \\
& \text { حرم الله إلا بالحق وأكل الربا وأكل مال اليتيم والتولي يوم الزحف وقذف المحصنات الغافلات } \\
& \text { المؤمنات }
\end{aligned}
$$

Artinya:

"Jauhilah tujuh perkara yang membinasakan, mereka berkata: wahai Rasulullah apakah ketujuh itu? Rasulullah berkata: menyekutukan Allah, melakukan sihir, membunuh jiwa yang diharamkan Allah kecuali dengan cara yang hak, memakan riba, memakan harta anak yatim, berpaling dari medan perang, menuduh zina tanpa bukti kepada perempuan yang suci lagi beriman." (H.R. Bukhari) ${ }^{13}$

Dari Jabir bin Abdullah raddiallahu 'anhuma berkata:

$$
\text { لعن رسول الله صلى الله عليه وسلم آكل الربا وموكله وشاهديه وقال: هم سواء }
$$

Artinya:

"Rasulullah șallallahu 'alaihi wa sallam melaknat orang yang memakan riba, memberi makan riba, dan dua yang menyaksikannya dan Rasulullah berkata, 'Mereka semua sama'." (H.R. Muslim) ${ }^{14}$

Pelarangan riba tentu karena terdapat mafsadāt yang besar di dalamnya dan terdapat dampak buruk bagi kehidupan pribadinya, sosial, dan ekonomi. ${ }^{15}$ Dampak buruk riba bagi personnya bahwa hati orang yang memakan harta riba akan terjangkiti penyakit egois, rakus, pelit, dan menuhankan harta sampai batas Allah sifati mereka dengan kemasukan setan. Adapun dampak buruknya bagi kehidupan sosial dapat menyebabkan perpecahan, kedengkian, permusuhan dalam kehidupan bermasyarakat. Sedangkan dampak buruknya bagi perekonomian yaitu dapat menghalangi masyarakat untuk melakukan usaha dengan produksi yang bermanfaat dan riba menyebabkan meningkatnyaharga-harga barang dan jasa. ${ }^{16}$

\section{Jenis-Jenis Riba dan $A s ̣ n a \bar{f}$-nya}

Riba berdasarkan bentuk transaksinya terbagi menjadi dua jenis yaitu riba pada utang piutang dan riba pada jual beli. Dikarenakan pokok pembahasan pada artikel ini adalah komoditas emas, maka pembahasannya masuk dalam jenis riba pada jual beli. Riba pada jual beli, sebagaimana yang telah disebutkan sebelumnya terdiri dari dua jenis, yaitu riba al-fạ̣l dan riba al-nasī'ah.

\footnotetext{
${ }^{13}$ Muhammad Al-Bukhari, Sahih Al-Bukhari (Dar Ul-Hadith, 1978).

${ }^{14}$ Muslim Al-Naisaburi, Shahih Muslim (Kairo: Dar Al-Ta'shil, n.d.).

15 Azwar Iskandar, Bayu Taufiq Possumah, and Khaerul Aqbar, "The Inflation And Poverty In Indonesia: Consequence Of Usury?,” Jurnal Ilmiah Al-Syir'ah 17, no. 2 (2019): 91-105.

${ }^{16}$ Syubili, Muqaddimah Fi Al-Mu'amalāti Al-Māliyah Wa Ba'dh Al-Tathbīqāt Al-Mu'āshirah.
} 


\section{Riba Al-Fadl}

Defenisi riba al-fadl adalah jual beli barang ribawi yang sejenis dengan takaran yang berbeda. Yang dimaksud dengan barang ribawi pada defenisi tersebut adalah barang yang terdampak oleh riba pada jual beli, yaitu barang yang 'illatnya adalah alat tukar atau makanan pokok yang dapat disimpan, sedangkan yang dimaksud dengan sejenis adalah barang-barangnya sama-sama barang ribawi. Maka emas dengan berbagai macam jenisnya adalah sejenis, kurma dengan berbagai macam jenisnya sejenis, dan mata uang real Saudi dengan berbagai macam bentuknya uang kertas atau logam juga sejenis. Sedangkan yang dimaksud berkelebihan adalah tidak sama takarannya atau timbangannya. ${ }^{17}$

Contoh transaksi riba al-fạ̣l yaitu, menukar 1 gram kurma sukkari dengan 2 gram kurma khallas dengan cara tunai, atau menukar 100 gram emas yang baru dengan 200 gram emas yang tua dengan cara tunai, atau menukar Rp. 10.000 uang kertas dengan Rp. 15.000 uang koin dengan cara tunai, maka semua contoh tersebut terlarang karena terdapat padanya riba al-fad, karena syarat riba al-faḍl adalah tukar-menukar barang ribawi dengan 'illat dan jenisnya sama.

Dalil pengharaman riba $a l-f a d ̣ l$ adalah hadis yang diriwayatkan oleh Ubadah bin Shamit raḍiallahu anhu dari Nabi șallallahu 'alaihi wa sallam bersabda

$$
\begin{aligned}
& \text { الذهب بالذهب والفضة بالفضة والتمر بالتمر والبر بالبر والملح بالملح والشعير بالشعير مثلا بمثل } \\
& \text { سواؤ بسواؤ يدا بيد فإذا اختلفت هذه الأصناف فبيعواكيف شئتم إذا كان يدا بيد }
\end{aligned}
$$

Artinya:

"Emas dengan emas, perak dengan perak, kurma dengan kurma, tepung dengan tepung, garam dengan garam, gandum dengan gandum, harus semisal, harus serupa, harus tangan dengan, apabila berbeda aṣnafnya maka juallah bagaiamanpun yang kalian inginkan." 18

\section{Riba al-Nasī'ah}

Defenisi riba al-nasī'ah adalah riba yang disebabkan karena penundaan atau pentakhiran, yaitu tukar-menukar barang ribawi dengan barang ribawi yang sama 'illatnya dan tidak secara kontan atau tunai. Yang dimaksud dengan yang sama 'illatnya adalah barang-barang yang akan ditukarkan adalah barang ribawi yang sama kategorinya, yang dimana kedua-duanya sebagai alat tukar, atau kedua-duanya adalah makanan pokok yang dapat disimpan, baik sama jenisnya atau berbeda. Sedangkan yang dimaksud kontan adalah menerima langsung barangnya secara tunai saat majelis akad berlangsung.

\footnotetext{
${ }^{17}$ Syubili.

${ }^{18}$ Al-Naisaburi, Shahih Muslim.
} 
Contoh riba al-Nasi'ah yaitu, menukar 1 gram kurma dengan 1 gram gandum dengan menerima kurmanya hari ini sedangkan gandumnya diserahkan besok hari, atau menukar 1 gram emas dengan 1 gram emas tidak secara kontan, atau menukar Rp. 1.000.000 pecahan lima puluhan dengan Rp. 1.000.000 pecahan seratus tidak secara kontan. ${ }^{19}$ Semua contoh yang disebutkan adalah jual beli terlarang karena terdapat padanya riba al-nasì'ah.

Dalil yang mengharamkan bentuk riba ini adalah hadis dari Umar bin Al-Khattab raḍiallahu 'anhu bahwasanya Nabi șallallahu 'alaihi wa sallam bersabda:

الذهب بالذهب ربا إلا هاء بهاء والبر بالبر ربا إلا هاء والشعير بالشعير ربا إلا هاؤ بهاء والتمر بالمر ربا إلا

$$
\text { هاء بهاء }
$$

Artinya:

"Emas dengan emas riba kecuali secara kontan, dan terigu dengan terigu riba kecuali secara kontan, dan gandum dengan gandum riba kecuali secara kontan, dan kurma dengan kurma riba kecuali secara kontan." (H.R. Bukhari) ${ }^{20}$

Hadis tersebut menunjukkan akan kewajibannya melakukan transaksi dengan barang ribawi secara kontan atau tunai, dan hadis sebelumnya pada hadis Ubadah mnunjukkan kewajiban jual beli barang ribawi yang sama'illatnya hanya mempersyaratkan dengan cara kontan, artinya apabila 'illatnya sama tapi berbeda jenis seperti tukar-menukar emas dengan perak maka dibolehkan berbeda takarannya atau jumlahnya, karena tidak terpenuhi padanya syarat riba al-fadll.

\section{Aṣnäf Al-Riba}

Aṣnāf adalah bentuk jamak dari șinf yang artinya varietas, aṣnāf al-riba adalah harta benda yang dapat dikenai hukum riba dalam transaksinya. Asंnāf al-riba atau barang-barang ribawi adalah barang-barang yang disebutkan secara tekstual pada hadis Ubadah yang kemudian ulama berijtihad menyimpulkan 'illatnya yang terdiri dari dua jenis, yaitu alat tukar atau makanan pokok yang dapat disimpan. 'Illat alat tukar mencakup emas dan perak dan juga ikut disertakan barang-barang yang tidak disebutkan dalam hadis yang memiliki illat yang sama yaitu alat tukar, seperti uang dengan berbagai macam mata uangnya. Dalam Bidayah, Ibnu Rusyd mengutip: "'Illat larangan jual beli emas yang harus sama itu (dalam satu jenis) karena sebagai alat pembayaran. Imam Syafi'i sependapat dengan Imam Malik bahwa 'Illat larangan jual beli emas dan perak (harus tunai dan sama) bahwa keduanya sebagai alat tukar. Dan 'Illat tersebut menurut mereka berlaku apabila penukaran antara jenis berbeda.

\footnotetext{
${ }^{19}$ Syubili, Muqaddimah Fi Al-Mu'amalāti Al-Māliyah Wa Ba'dh Al-Tathbīqāt Al-Mu'āshirah.

${ }^{20}$ Al-Bukhari, Sahih Al-Bukhari.
} 
Tetapi, jika satu jenis, maka harus sama. ${ }^{21}$ Maka, jenis uang kertas, logam, elektronik, dan lain-lain selama diakui sebagai alat tukar maka termasuk dalam ashnaf al-riba, yang diambil hukum qiyasnya dari emas dan perak. ${ }^{22}$

'Illat yang kedua adalah makanan pokok yang dapat disimpan, yaitu gandum, terigu, kurma, garam. Maka, diikutkan dengannya barang-barang yang tidak disebutkan dalam teks hadis akan tetapi memiliki 'illat yang sama seperti beras, jagung, biji-bijian dan semisalnya. Adapun yang bukan makanan pokok dan tidak dapat disimpan tidak termasuk barang ribawi seperti buah-buahan, sayur-sayuran, susu, dan lain-lain. ${ }^{23}$ Landasan hukumnya adalah qiyās sebagaimana pada uang diqiyaskan atas emas, maka beras diqiyaskan atas gandum, terigu dan lain-lain.

\section{Kaedah-Kaedah Riba pada Jual beli}

Dalam bertransaksi dengan așnaf al-riba harus memperhatikan kaedah-kaedah riba, karena apabila tidak memperhatikannya akan terjatuh pada transaksi riba. Adapun kaedah-kaedah dalam bertransaksi dengan barang-barang ribawi, baik itu emas, perak, ataupun uang kertas, uang elektronik, dan gandum, terigu, kurma, garam, ataupun beras dan jagung adalah sebagai berikut: ${ }^{24}$

1. Tukar-menukar dua barang ribawi dengan jenis yang sama seperti emas ditukar dengan emas atau mata uang rupiah ditukar dengan rupiah, maka syarat sah dalam akad jual beli ini ada dua, yang pertama harus sama takaran atau nilainya dan yang kedua harus kontan sebelum berpisah dari majelis akad. Contohnya: membeli emas tua1 gram dengan emas baru 1 gram pula, atau Rp. 10.000 uang kertas dengan 10 buah uang koin pecahan Rp. 1.000. Apabila syarat pertamnya yaitu takarannya sama tidak terpenuhi maka jadi riba $a l-f a d l$, dan jika syarat yang kedua tidak terpenuhi yaitu secara kontan maka jadi riba al-nasiah, dan jika kedua syaratnya tidak terpenuhi, maka transaksinya jadi riba al-fạ̣l al-nasì'ah.

2. Tukar-menukar dua barang ribawi yang berbeda jenis tapi sama 'illat-nya, seperti tergiu ditukar dengan gandum, atau emas ditukar dengan perak, atau emas ditukar dengan uang rupiah, atau uang rupiah dengan uang dollar. Maka, untuk sahnya transaksi tersebut harus terpenuhi satu syarat saja yaitu kontan sebelum berpisah dari majelis akad, dan tidak dipersyaratkan harus sama nominal atau takarannya. Contohnya, membeli emas batangan 1 gram dengan uang Rp. 700.000, maka syaratnya harus kontan sebelum berpisah dari majelis akad, yaitu pembeli menyerahkan uangnya kontan dan penjual menyerahnya emasnya saat itu juga.

\footnotetext{
${ }^{21}$ Ibnu Rusyd Al-Qurthubi, Bidayatu Al-Mujtahid Wa Nihayatu Al-Muqtashid (Madinah: Dar AlKhudhairi, 1998), h. 481.

${ }^{22}$ Ibnu Qudamah Al-Maqdisiy, Rauḍatu Al-Nāzhir Wa Junnatu Al-Munāzir (Riyadh: AlMaktabah Al-Tadmuriyah, 1998).

${ }^{23}$ Syubili, Muqaddimah Fi Al-Mu'amalāti Al-Māliyah Wa Ba'dh Al-Tathbīqāt Al-Mu'āshirah.

${ }^{24}$ Syubili.
} 
Apabila tidak terpenuhi satu syarat tersebut yaitu kontan atau tunai maka jadilah transaksi tersebut riba al-nasi'ah dan tidak terdapat pada bentuk transaksi tersebut riba al-fadl.

3. Tukar-menukar dua barang ribawi yang berbeda jenisnya dan juga 'illat-nya, seperti kurma ditukar dengan emas, atau terigu ditukar dengan uang rupiah. Maka sahnya transaksi tersebut tidak dipersyaratkan kontan (saling terima barang) dan sama takaran atau nilainya. Contohnya, membeli 1 kilogram kurma dengan uang Rp.100.000 secara kontan ataupun tidak maka tidak terdapat riba al-nasi'ah maupun riba al-fadl pada transaksi tersebut.

4. Tukar-menukar barang ribawi dengan barang yang bukan ribawi, seperti mobil ditukar dengan uang rupiah atau rumah ditukar dengan emas. Maka sahnya transaksi tersebut tidak dipersyaratkan kontan (saling terima barang) dan sama takaran atau nilainya. Contohnya, membeli mobil dengan harga Rp. 100.000.000 secara kontan ataupun tidak maka tidak terdapat riba al-nasi'ah maupun riba alfaḍl pada transaksi tersebut.

5. Tukar-menukar dua barang yang keduanya bukan ribawi, seperti jam tangan ditukar dengan handphone, atau mobil tua dengan motor baru. Maka sahnya transaksi tersebut tidak dipersyaratkan kontan (saling terima barang) dan sama takaran atau nilainya. Transaksi seperti ini baik secara kontan ataupun tidak maka tidak terdapat riba al-nasi'ah maupun riba al-fadl pada transaksi tersebut.

Pengharaman riba al-fạll dan riba al-nasī'ah adalah bentuk pencegahan atau menutup pintu-pintu transaksi-transaksi yang terlarang, hal itu dikarenakan riba al-faḍl terdapat penambahan pada akadnya tanpa penundaan, sedangkan riba al-nasī'ah terdapat penundaan tanpa penambahan pada akadnya, dan keduanya dapat membuat pelakunya terjatuh pada riba yang lebih besar yaitu riba pada piutang yang telah terjadi pada zaman jahilyah. Karena riba jahiliyah adalah gabungan dari riba al-fậl dan riba al-nasì'ah yang pada akadnya terdapat penambahan dan penundaan. Berkata Ibnu AlQayyim sesungguhnya Allah mengharamkan membedakan pada șarf (tukar-menukar uang) dan jual beli riba dengan sejenisnya sebelum menerimanya, agar tidak menjadikan hal itu pada penundaan yang dimana itu adalah pokok riba. ${ }^{25}$

\section{Emas dalam Perspektif Ușūl Fiqh}

Komoditas dalam Fikih Muamalah dikenal dengan al-mabì' atau 'arḍ yang merupakan salah satu rukun dari akad jual beli yaitu al-ma'qūd 'alaihi (objek akad) yang syaratnya adalah harus mubāh al-manfa'ah hukumnya boleh untuk dimanfaatkan dalam perspektif hukum Islam, maka barang yang diperjual belikan tidak boleh dari

${ }^{25}$ Ibnu Al-Qayyim Al-Jauziyah, I'lam Al-Muwaqi '̄n 'an Rabbi Al-'Ālamin (Saudi: Dar Ibnu AlJauziy, 2002). 
benda-benda yang diharamkan dalam Islam seperti khamar, daging babi, anjing dan lain-lain. Dalilnya adalah sabda Rasulullah șallallahu 'alaihi wa sallam :

$$
\text { إن الله إذا حرم على قوم أكل شيئ حرم عليهم ثمنه (رواه أحمد) }
$$

Artinya:

"Sesungguhnya Allah apabila mengharamkan atas suatu kaum memakan sesuatu, maka Allah-pun mengharamkan atas mereka harganya." (H.R. Ahmad) ${ }^{26}$

Dan syarat lainnya apabila barang tersebut termasuk dalam kategori aṣnāf al-riba, maka berlaku kaedah riba pada transaksi atas barang tersebut yang apabila tidak terpenuhi ketentuan-ketentuannya maka transaksi tersebut menjadi haram karena terdapatnya riba pada transaksi tersebut.

Sejak dahulu, emas memiliki dua fungsi yaitu sebagai alat tukar berupa uang yang terbuat dari emas dan fungsi komoditas yang berupa emas batangan dan perhiasan. Ibnu Taimiyah dan Ibnu al-Qayyim menegaskan, jika emas tidak lagi difungsikan sebagai uang, misalnya telah dijadikan perhiasan, emas tersebut berstatus sama dengan barang, Ibnu al-Qayyim berkata perhiasan dari emas atau perak) yang diperbolehkan, karena dengan produksi, statusnya berubah menjadi (seperti) jenis pakaian dan barang, bukan jenis harga. ${ }^{27}$ Sedangkan Sykeh Mani' menyebutkan bahwa emas atau perak yang sudah dibentuk (menjadi perhiasan) itu tidak lagi sebagai harga, maka boleh ada kelebihan dalam mempertukarkan antara yang sejenis tetapi tidak boleh ada pengangguhan. ${ }^{28}$ Sedangkan Ulama yang tergabung dalam Al-Lajnah al-Dā'imah lil Iftà' menyebutkan bahwa apabila salah satu yang ditukarkan adalah emas yang telah diolah dan yang lainnya adalah alat tukar (uang) maka boleh berbeda nilai akan tetapi harus tunai sebelum berpisah dari majelis akadnya. ${ }^{29}$

Berdasarkan beberapa pendapat yang telah disebutkan sebelumnya, dapat disimpulkan bahwa semuanya sependapat bahwa emas yang difungiskan sebagai alat tukar berlaku padanya kaedah riba, sebagaimana mereka sepakat bahwa emas yang telah diolah menjadi emas batangan atau perhiasan dihukumi sebagai komoditas atau mabì', namun mereka berbeda pendapat pada emas yang telah diolah tersebut apakah boleh diperjual belikan dengan cara tidak tunai atau tidak boleh. Hal itu disebabkan perbedaan pemahaman mereka terhadap așnāf al-riba yang disebutkan dalam hadis Rasulullah șallallahu 'alaihi wa sallam dari 'Ubādah bin Sāmit, "(Jual beli) emas dengan emas, perak dengan perak ... (dengan syarat harus) sama dan sejenis serta secara tunai. Jika

\footnotetext{
${ }^{26}$ Imam Ahmad Ibnu Hanbal, Musnad Al-Imam Ahmad Bin Hanbal (Riyadh: Dar Al-Salam, 2013).

${ }^{27}$ Al-Jauziyah, I'lam Al-Muwaqi'̄̄n 'an Rabbi Al- 'Ālamin.

${ }^{28}$ Abdullah Al-Mani', Buhūts F̄̄ Al-Iqtiṣād Al-Islamiy (Mekkah: Al-Maktab Al-Islamiy, 1996), h. 332.

${ }^{29}$ Lajnah Da'imah, Fatāwā Al-Lajnah Al-Dā'imah Li Al-Buhuts Al-'Ilmiyah Wa Al-Ifta' (Riyadh: Mu'assasah Al-Amirah, 2018), j. 13, h. 483-85.
} 
jenisnya berbeda, juallah sekehendakmu jika dilakukan secara tunai." (H.R. Muslim) ${ }^{30}$ Dan hadis dari Umar bin Khatthab, "Emas dengan perak adalah riba kecuali secara tunai." (H.R. Muslim) ${ }^{31}$

Ulama yang berpendapat emas yang dimaksud pada hadis Rasulullah adalah semua fungsi emas, baik itu sebagai alat tukar maupun komoditas yang berupa emas batangan atau perhiasan, maka berlaku pada emas-emas tersebut kaedah-kaedah riba. Sedangkan ulama yang berpendapat bahwa emas yang dimaksud pada hadis tersebut hanyalah emas yang berfungsi sebagai alat tukar, maka kaedah-kaedah riba hanya berlaku pada emas yang berfungsi sebagai alat tukar dan tidak berlaku pada fungsifungsi emas lainnya, seperti emas batangan ataupun emas perhiasan. Perbedaan tersebut didasari oleh perbedaan pemahaman pada disiplin ilmu Ushul Fikih, tepatnya pada pembahasan qiyas dalam menentukan 'illat al-hukm.

'Illat al-hukm secara bahasa adalah penyakit atau yang merubah keadaan, sedangkan secara istilah adalah sifat yang nampak dan erat yang ditunjuk oleh dalil sebagai tempat bergantungnya suatu hukum padanya. ${ }^{32}$ Dan dalam menentukan illat terdapat tiga metode, yaitu:

(1) Tahqūq al-manāt yang mana 'illat suatu hukum disebutkan dengan jelas dalam teks Al-Qur'an, Hadis atau Ijma' seperti hukum air bekas jilatan kucing Rasulullah sallallahu 'alaihi wasallam bersabda:

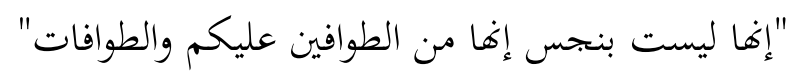

"Sesungguhnya kucing itu tidaklah najis, sesungguhnya kucing itu termasuk yang berkeliaran di sekitar kalian." (HR. Abu Daud ${ }^{33}$, Tirmidzi ${ }^{34}$, dan Ahmad $^{35}$ )

Maka 'illat dihukuminya kucing tidak najis karena kucing termasuk hewan yang berkeliaran di sekitar manusia.

(2) Tanqīh al-manāt yang mana 'illatnya tidak disebutkan melainkan sebab hukumnya yang memiliki sifat-sifat, kemudian menghapus sifat-sifat yang tidak tepat dijadikan illat pada suatu hukum. Seperti hukum diwajibkan kaffarat apabila berhubungan badan di siang hari pada bulan Ramadan, maka sifat-sifat yang disebutkan dalam hadis tersebut adalah arab badui, berhubungan badan, siang hari, bulan Ramadan, perempuannya adalah istrinya. Kemudian menghapus sifat-sifat yang tidak ada pengaruhnya pada hukum, maka tersisalah sifat yang menjadi 'illat, yaitu berhubungan badan pada siang hari di bulan Ramadan.

\footnotetext{
${ }^{30}$ Al-Naisaburi, Shahih Muslim.

${ }^{31}$ Al-Naisaburi.

${ }^{32}$ Iyadh Al-Salami, Ușūl Al-Fiqh Al-Ladzī Lā Yasa'u Al-Faqīh Jahluh (Riyadh: Dar alTadmuriyah, 2005), h. 146.

${ }^{33}$ Abu Dawud Al-Sijistani, Sunan Abi Dawud (Beirut: Al-Maktabah Al-’Asriyyah, n.d.).

${ }^{34}$ Muhammad bin 'Isa Al-Tirmidzi, Sunan Al-Tirmidzi (Maktbah Mustafa Al-Halbi, 1975).

${ }^{35}$ Ibnu Hanbal, Musnad Al-Imam Ahmad Bin Hanbal.
} 
(3) Takhrīj al-manāt yang mana hukum yang disebutkan dalam teks Al-Qur'an, Hadis atau Ijma' tidak disertai 'illat maupun sifat-sifat yang ada pada hukum tersebut. Maka, Ulama berijtihad dalam menentukan 'illatnya, seperti pengharaman meminum khamar karena dzatnya yang memabukkan maka diqiyaskan atasnya pelarangan meminum nabïz yang juga memabukkan, dan seperti riba yang terdapat pada gandum karena makanan pokok yang dapat ditimbang maka diqiyaskan atasnya beras yang juga dapat ditimbang. ${ }^{36}$

Penyebutan emas dalam hadis tentang riba baik dalam hadis Ubadah bin Shamit dan Umar bin Khattab tidak disertai dengan penyebutan 'illat maupun sebab yang terdapat sifat-sifatnya, maka dalam menentukan 'illatnya dengan metode takhrīj almanāt, yaitu Ulama berijtihad dalam menentukan 'illat al-hukm yang akan menghasilkan ijtihad yang berbeda-beda, maka dalam perselisihan tersebut ada hasil ijtihad yang benar dan ada yang salah, dan kita dianjurkan mengambil hasil ijtihad yang benar atau lebih mendekati kebenaran. Berkata Ibnu Qudamah bahwa kebenaran hanya pada dari para mujtahidin dan selain dari padanya adalah salah, baik dalam urusan cabang agama dan pokok agama, akan tetapi apabila pada urusan cabang agama yang tidak terdapat dalil qāti' dari Al-Qur'an, hadis atau ijma', maka mujtahid tersebut mendapatkan udzur tidak berdosa dan mendapatkan pahala atas ijtihadnya. ${ }^{37}$ Berdasarkan sabda Rasulullah șallallahu 'alaihi wa sallam:

$$
\text { "إذا حكم الحاكم فاجتهد ثم أصاب فله أجران وإذا حكم فاجتهد ثم أخطأ فله أجر" رواه البخاري }
$$

Artinya:

"Apabila seorang hakim berijtihad kemudian dia benar maka dia mendapatkan dua pahala, dan apabila dia salah maka dia mendapatkan satu pahala." (H.R. Bukhari) ${ }^{38}$

Para ulama bersepakat pada harta riba adalah ke enam aṣnāf al-rib $\bar{a}$ yaitu emas, perak, gandum bulat, gandum panjang, kurma dan garam. Sebagaimana ijma' yang dinukilkan oleh Ibnu Rusyd setelah menyebutkan ke enam harta riba beliau berkata: semua itu telah disepekati oleh para Ahli Fikih. ${ }^{39}$ Akan tetapi, para ulama berbeda pendapat dalam menentukan 'illat pada al-așnăf al-ribawiyah dan perbedaan mereka itu didasari atas perbedaan metode ijtihad mereka masing-masing.

1) Madzhab Hanafiyah dan Hanabilah berpendapat bahwah 'illat pada riba al-faḍ adalah volume dan berat apabila satu sinf dan riba al-nasa' apabila 'illat nya sama. $^{40}$

\footnotetext{
${ }^{36} \mathrm{Al}$-Maqdisiy, Raudatu Al-Nāzhir Wa Junnatu Al-Munāzir.

${ }^{37}$ Al-Maqdisiy.

${ }^{38}$ Al-Bukhari, Sahih Al-Bukhari.

${ }^{39}$ Al-Qurthubi, Bidayatu Al-Mujtahid Wa Nihayatu Al-Muqtashid.

${ }^{40}$ Kamal bin Sayyid Salim, Sahīh Figh Al-Sunnah Wa Adillatuh Wa Tawḍih Mażāhib AlA'immah (Kairo: Dar Al-Tawqifiyah litturāts, 2010), h. 273.
} 
2) Madzhab Malikiyah berpendapat bahwa 'illat riba al-faḍl pada emas dan perak adalah harga apabila satu șinf, sedangkan 'illat riba al-nasa' pada empat așnāf lainnya adalah makanan pokok yang dapat disimpan apabila satu sinf. ${ }^{41}$

3) Madzhab Syafi'iyah berpendapat bahwa 'illat riba al-fadl dan al-nasa' adalah harga pada emas dan perak, dan makanan pada empat as்nāf yang tersisa. ${ }^{42}$

4) Ibnu Taimiyah berpendapat bahwa 'illat pada pada empat aṣnăf adalah volume dan berat, sedangkan 'illat pada emas dan perak adalah harga, karena 'illatnya dapat berlaku pada yang lainnya seperti uang logam dan uang kertas. ${ }^{43}$

Perbedaan ulama dalam menentukan 'illat pada aṣnăf al-ribā diperuntukan dalam menentukan barang-barang yang lain yang tidak disebutkan dalam hadis yang menjadi harta riba, sehingga barang-barang yang lain yang juga terdapat padanya 'illat așnāf alriba maka akan dihukumi sebagai harta riba dan berlaku padanya kaedah-kaedah riba. Seperti uang kertas memiliki 'illat harga dan beras memiliki 'illat makanan pokok yang dapat disimpan, sehingga uang kertas dan beras termasuk harta riba yang berlaku padanya kaedah-kaedah riba. Adapun harta riba yang disebutkan dalam hadis yang jumlahnya ada enam yang dikenal dengan al-aṣnāf al-ribawiyah, maka berlaku pada ke enam harta riba tersebut kaedah-kaedah riba sampai kapanpun, apapun bentuknya dan bagaimanapun fungsinya, bahkan apabila diolah sehingga bercampur dengan benda lain, maka harus dipishkan perhitungannya pada volume atau berat.

Berkata Ibnu 'Utsaimin rahimahullah, "Yang paling tepat yang dapat dikatakan bahwa 'illat pada emas dan perak adalah asalnya berupa emas dan perak, baik berupa alat tukar maupun bukan (komoditas). Dan dalil yang menunjukkan bahwa emas dan perak yang tidak berfungsisebagai alat tukar termasuk harta riba adalah hadis tentang kalung yang diriwayatkan oleh Faḍālah bin 'Ubaid bahwasanya beliau membeli kalung yang terdapat emas dan manik-manik dengan harga 12 dinar, maka diapun memisahkan emas dan manik-manik itu dan mendapati emasnya lebih banyak dari 12 dinar, maka Rasulullah melarang menjualnya sampai dipisahkan (H.R. Muslim) ${ }^{44}$. Dan diketahui bahwasanya kalung tidak termasuk alat tukar, maka berdasarkan hal ini riba terdapat pada emas dan perak baik sebagai alat tukar, atau emas dan perak batangan maupun sebagai perhiasan bagaimanapun bentuknya dan riba tidak terdapat pada besi, baja dan barang tambang lailnnya." 45

Dalam hadis yang dinukil Ibnu 'Utsaimin bahwa kalung adalah perhiasan yang terdapat padanya emas dan manik-manik tetap dihukumi sebagai emas yang mana riba berlaku padanya, sehingga ketika hendak ditukar dengan dinar sedangkan dinar terbuat dari emas maka berlaku padanya kaedah riba yaitu tukar-menukarnya harus sama

\footnotetext{
${ }^{41}$ Al-Qurthubi, Bidayatu Al-Mujtahid Wa Nihayatu Al-Muqtashid.

${ }^{42}$ Al-Qurthubi.

${ }^{43}$ Salim, Sahīh Fiqh Al-Sunnah Wa Adillatuh Wa Tawḍ̄h Mażāhib Al-A'immah.

${ }^{44}$ Al-Naisaburi, Shahih Muslim.

${ }^{45}$ Salim, Sahīh Fiqh Al-Sunnah Wa Adillatuh Wa Tawdīh Mażāhib Al-A 'immah.
} 
nilainya dan harus kontan serah terimanya dalam satu majelis. Hal itu yang membuat Rasulullah melarang Faḍālah bin 'Ubaid untuk menjual kalung tersebut kecuali setelah dipisahkan terlebih dahulu antara manik-manik dan emas, sehingga dapat ketahuan berapa nilai emas pada kalung tersebut yang tidak boleh berat emasnya melebihi meas pada dinar. Sedangkan salam hadis tersebut sahabat Faḍālah mendapati berat emas pada kalung lebih berat daripada emas pada 12 dinar.

\section{Istidläl Penetapan Fatwa DSN-MUI ${ }^{46}$}

Dalam penetapan fatwa DSN-MUI menyebutkan dalil-dalil dari al-qur'an dan Hadis yang berkaitan riba yang sudah disebutkan sebelumnya, dan menyebutkan kaidah ushul fikih yiatu "hukum berputar (berlalu) bersama ada atau tidakadanya 'illat". Pengertian kaidah ushul fikih tersebut adalah bahwa'illat yang terdapat pada sesuatu maka hukumnya ada, jika 'illat-nya tidak ada maka hukumnyapun tidak ada, seperti 'illat pada emas adalah alat tukar, jika emas berfungsi sebagai alat tukar maka emas tersebut transaksinya harus tunai dan jika fungsi sebagai alat tukar sudah tidak ada maka emas tersebut dapat ditransaksikan tidak tunai. ${ }^{47}$

Menurut peneliti, kaidah ini digunakan pada dua hal: 1) untuk menentukan illat suatu hukum seperti khamar diharamkan karena memabukkan, jika khamar telah berubah (dengan sendirinya mnjadi cuka sehingga tidak memabukkan lagi, maka khamar tersebut tidak haram, maka 'illat pada pengharaman khamar adalah dapat memabukkan ${ }^{48}$; 2) untuk menentukan hukum pada al-far'u (perkara yang tidak disebutkan dalam al-Qur'an, Hadis dan Ijmak), seperti tape jika sampai memabukkan karena tersimpan sangat lama, maka dihukumi haram seperti khamar. Sedangkan emas adalah al-așlu (perkara yang disebutkan secara tekstual dalam al-Qur'an, Hadis dan Ijmak), maka hukumnya tidak berubah walaupun 'illatnya sudah tidak ada. ${ }^{49}$

DSN-MUI juga menyebutkan beberapa pendapat ulama yang dijadikan landasan fatwanya, yaitu perkataan Ibnu Taimiyah,

$$
\begin{aligned}
& \text { "ويجوز بيع المصوغ من الذهب والفضة بججنه من غير اشتراط التماثل, ويجعل الزائد في مقابلة } \\
& \text { الصنعة سواء كان البيع حالا أو مؤجلا ما لم يقصد كوهما ثثنا" }
\end{aligned}
$$

Artinya:

"Boleh melakukan jual beli perhiasan yang terbuat dari emas dan perak dengan jenisnya tanpa syarat harus sama kadarnya, dan kelebihannya dijadikan sebagai kompensasi atas jasa pembuatannya, baik jual beli itu dengan pembayaran tunai maupun dengan

\footnotetext{
${ }^{46}$ Dewan Syariah Nasional MUI, "Fatwa DSN MUI No. 77/DSN-MUI/2010 Tentang Jual Beli Emas Secara Tidak Tunai."

${ }^{47}$ Ali Ahmad al-Nadawiy, Mawsu'ah Al-Qawa'id Wa Al-Dhawabith Al-Fiqhiyah Al-Hakimah Li Al-Mu'amalat Al_maliyah Fi Al-Fiqh Al-Islamiy (Riyadh: Dar 'Alam al-Ma'rifah, 1999), h. 395.

${ }^{48}$ Al-Maqudisiy, Rauḍatu Al-Nāzhir Wa Junnatu Al-Munāzir.

${ }^{49}$ Al-Maqdisiy.
} 
pembayaran tangguh, selama emas dan perak tersebut tidak dimaksudkan sebagai harga (uang).,, 50

Jual beli emas yang dibolehkan secara tidak tunai dalam fatwa Ibnu Taimiyah adalah perhiasan yang terbuat dari emas, dan boleh ditukar dengan emas dengan takaran yang tidak sama, karena kelebihannya adalah upah dari biaya produksinya. Maka, menurut Ibnu Taimiyah perhiasan yang terbuat dari emas bukan lagi emas murni sehingga tidak termasuk așnāf ribawiyah. Hal itu, karena telah melalui proses produksi dan bercampur dengan perhiasan-perhiasan lainnya seperti manik-manik, intan, pertama, besi dan lain-lain.

Meskipun pendapat Ibnu Taimiyah menyelisihi jumhur Ulama termasuk Empat Imama Mazhab, bukan berarti Ibnu Taimiyah berpendapat emas murni yang tidak berfungsi sebagai alat tukar dihukumi telah keluar dari aśnäf ribawiyah. Karena sudah menjadi Ijmak Ulama pada suatu kaidah Lā Masāga li al-Ijtihād fĭ Maurid al-Naś (tidak diperbolehkan berijtihad selama masih ada nas), ${ }^{51}$ dan berkata Ibnu al-Qayyim telah dinukilkan secara makna dari perkataan Ulama bahwa gugurnya suatu ijtihad apabila terdapat nas padanya. ${ }^{52}$ Karena Ibnu Taimiyah termasuk di antara Ulama yang menyepakati kaidah tersebut, dan emas adalah permasalahan yang terdapat nas padanya sehingga tidak boleh berijtihad padanya, sedangkan illat pada emas adalah alat tukar merupakan hasil ijtihad, maka gugurlah ijtihad 'illat tersebut pada emas murni.

\section{KESIMPULAN}

Berdasarkan hasil pembahasan di atas, dapat disimpulkan bahwa emas yang berfungsi sebagai komoditas tetap dihukumi salah satu dari al-așnāf al-ribawiyah, dan pendapat yang mengatakan emas yang tidak berfungsi sebagai alat tukar telah keluar dari kategori al-aṣnāf al-ribawiyah tidaklah berlandaskan dengan argument yang kuat, hal itu dikarenakan: Pertama, Rasulullah șallallahu 'alaihi wa sallam ketika menyebutkan al-aṣnāf al-ribawiyah tidak mengkhususkan pada salah satu fungsi emas dan sejak jaman dahulu fungsi emas selain alat tukar sudah ada; kedua, Larangan Rasulullah șallallahu 'alaihi wa sallam membeli perhiasan dari emas dan manik-manik dengan dinar sebelum diketahui nilai dari kandingan emas pada perhiasan tersebut; Ketiga, Tidak adanya penjelasan baik dari Rasulullah, Sahabat dan Tabi'in yang mengkhususkan emas yang dimaksud hanya pada fungsi alat tukar, adapun penukilan beberapa pendapat Ulama tentang 'illat emas adalah yang diperuntukkan hukumnya pada selain yang tidak disebutkan dalam nas dan tidak adanya pernyataan tegas dari

\footnotetext{
${ }^{50}$ Alauddin Al-Dimsasyqiy, Al-Ikhtiyarat Al-Fiqhiyah Min Fatwa Syaikh Ibn Taimiyah (AlQahirah: Dar al-Istiqamah, 2005), h. 146.

${ }^{51}$ Jahada Mangka and Muh Isra Syarif, "Implementasi Kaidah 'Lā Masāga Li Al-Ijtihād Fī Maurid Al-Naṣ’ Dalam Fikih Islam,” BUSTANUL FUQAHA: Jurnal Bidang Hukum Islam 2, no. 1 (2021): 24-37.

${ }^{52}$ Al-Jauziyah, I'lam Al-Muwaqi' ìn 'an Rabbi Al-'Ālamin.
} 
mereka mengatakan "emas selain berfungsi sebagai alat tukar keluar dari kategori alașnāf al-ribawiyah".

Implikasi dari hasil penelitian ini bahwa transaksi pada emas yang sebagai komoditas harus memperhatikan kaedah-kaedah riba yang telah dijelaskan sebelumnya, maka tidak dibolehkan jual beli emas secara tidak tunai, baik pada transaksi jual beli emas online, cicilan emas, tabungan emas dan lain-lainnya, itu semua karena tidak terealisasikannya serah terima secara tunai pada majelis akad. Oleh karean itu, Fatwa DSN MUI yang membolehkan emas selain alat tukar ditransaksikan dengan tidak tunai perlu untuk ditinjau kembali, karena banyaknya transaksi-transaksi emas secara tidak tunai yang menjadikan Fatwa DSN MUI tersebut sebagai landasan pada transksitransaksi mereka. Dan beberapa rekomendasi praktik bisnis dari peneliti terkait transaksi emas, yaitu: 1) Melakukan transaksi emas dengan tunai dengan bertemunya secara langsung antara penjual dan pembeli di majelis akad; 2) dapat pula jual-belinya diwakilkan kepada yang menjadi wakil dari tiap pihak, bukan wakil untuk kedua belah pihak.

\section{DAFTAR PUSTAKA}

Al-Bukhari, Muhammad. Sahih Al-Bukhari. Dar Ul-Hadith, 1978.

Al-Dimsasyqiy, Alauddin. Al-Ikhtiyarat Al-Fiqhiyah Min Fatwa Syaikh Ibn Taimiyah. Al-Qahirah: Dar al-Istiqamah, 2005.

Al-Jauziyah, Ibnu Al-Qayyim. I'lam Al-Muwaqi'̄in 'an Rabbi Al-'Ālamin. Saudi: Dar Ibnu Al-Jauziy, 2002.

Al-Mani', Abdullah. Buhūts F̄̄ Al-Iqtișād Al-Islamiy. Mekkah: Al-Maktab Al-Islamiy, 1996.

Al-Maqdisiy, Ibnu Qudamah. Rauḍatu Al-Nāzhir Wa Junnatu Al-Munāzir. Riyadh: AlMaktabah Al-Tadammuriyah, 1998.

al-Nadawiy, Ali Ahmad. Mawsu'ah Al-Qawa'id Wa Al-Dhawabith Al-Fiqhiyah AlHakimah Li Al-Mu'amalat Al_maliyah Fi Al-Fiqh Al-Islamiy. Riyadh: Dar 'Alam al-Ma'rifah, 1999.

Al-Naisaburi, Muslim. Shahih Muslim. Kairo: Dar Al-Ta'shil, n.d.

Al-Qurthubi, Ibnu Rusyd. Bidayatu Al-Mujtahid Wa Nihayatu Al-Muqtashid. Madinah: Dar Al-Khudhairi, 1998.

Al-Salami, Iyadh. Ușūl Al-Fiqh Al-Ladzì Lā Yasa'u Al-Faqīh Jahluh. Riyadh: Dar alTadmuriyah, 2005.

Al-Sijistani, Abu Dawud. Sunan Abi Dawud. Beirut: Al-Maktabah Al-'Asriyyah, n.d.

Al-Tirmidzi, Muhammad bin 'Isa. Sunan Al-Tirmidzi. Maktbah Mustafa Al-Halbi, 1975.

As-Sā'at̄̄, Abd. Rahim. “Al-'Illah Al-Iqtișādiyah Litahrīm Riba Al-Nasī’Ah Wa Al- 
Faḍl,", n.d.

Da'imah, Lajnah. Fatāwā Al-Lajnah Al-Dā'imah Li Al-Buhuts Al-'Ilmiyah Wa Al-Ifta'. Riyadh: Mu'assasah Al-Amirah, 2018.

Dewan Syariah Nasional MUI. "Fatwa DSN MUI No. 77/DSN-MUI/2010 Tentang Jual Beli Emas Secara Tidak Tunai,” 2010.

Hamzah, Imron. "Jual Beli Emas Secara Tidak Tunai Dalam Pandangan Ibn Taymiyyah (1263-1328 M).” IAIN Purwokerto, 2018.

Ibnu Hanbal, Imam Ahmad. Musnad Al-Imam Ahmad Bin Hanbal. Riyadh: Dar AlSalam, 2013.

Iskandar, Azwar, and Khaerul Aqbar. "Kedudukan Ilmu Ekonomi Islam Di Antara Ilmu Ekonomi Dan Fikih Muamalah: Analisis Problematika Epistemologis." NUKHBATUL 'ULUM: Jurnal Bidang Kajian Islam 5, no. 2 (2019): 88-105.

—. "Reposisi Praktik Ekonomi Islam: Studi Kritis Praktik Ekonomi Islam Di Indonesia.” NUKHBATUL'ULUM: Jurnal Bidang Kajian Islam 5, no. 1 (2019): 39-53.

Iskandar, Azwar, Bayu Taufiq Possumah, and Khaerul Aqbar. "The Inflation And Poverty In Indonesia: Consequence Of Usury?” Jurnal Ilmiah Al-Syir'ah 17, no. 2 (2019): 91-105.

Kementerian Agama, R I. "Al-Qur'an Dan Terjemahan.” Bandung: CV Mikraj Khazanah Ilmu, 2013.

—. Al-Quran Dan Terjemahnya. Jakarta: PT. Hati Emas, 2014.

Mangka, Jahada, and Muh Isra Syarif. "Implementasi Kaidah 'Lā Masāga Li Al-Ijtihād F̄̄ Maurid Al-Naș’ Dalam Fikih Islam.” BUSTANUL FUQAHA: Jurnal Bidang Hukum Islam 2, no. 1 (2021): 24-37.

Ramli, Abdul Rahman. "Jual Beli Emas Secara Tidak Tunai (Telaah Fatwa DSN-MUI No. 77/DSN-MUI/V/2010)." Universitas Muhammadiyah Surakarta, 2015.

Salim, Kamal bin Sayyid. Sahīh Fiqh Al-Sunnah Wa Adillatuh Wa Tawdīh Mażāhib AlA 'immah. Kairo: Dar Al-Tawqifiyah litturāts, 2010.

Syubili, Yusuf. Muqaddimah Fi Al-Mu'amalāti Al-Māliyah Wa Ba'dh Al-Tathbīqāt AlMu'āshirah. Makkah: Maktabah Nur, 2005.

Zamani, Ahmad Zaki. "Iistidlal Fatwa Dewan Syariah Nasional Tetang Jual Beli Emas Tidak Tunai." Al-Banjari: Jurnal Ilmiah Ilmu-Ilmu Keislaman 15, no. 1 (2016): 83-98. 